\title{
HUBUNGAN EMOTIONAL INTELLIGENCE TERHADAP KUALITAS HIDUP PASIEN DIABETES MELLITUS TIPE II DI PUSKESMAS GUGUAK PANJANG TAHUN 2018
}

\author{
Aulia Putri, Bella Lusia Ariska, Siska Damaiyanti
}

\begin{abstract}
Diabetes Mellitus (DM) which is a degenerative disease that requires proper treatment and serious. DM sufferers must undergo continuous therapy. This condition can lead to a variety of health changes that cause physical and psychological disorders for sufferers. One of them is emotional intelligence and poor quality of life. The purpose of this study was to analyze the Emotional Intelligence Relationship Against the Quality of Life of Type II Diabetes Mellitus Patients in Guguak Panjang Health Center in 2018. This type of research wasresearch descriptive analytic. With aapproach cross sectional. The sampling technique uses a total sampling with 82 respondents. The instrument used was the question of the level of emotional intelligence and the quality of life questionnaire in patients with DM. The results of the chisquere test showed that there was an Emotional Intelligence Relationship to the Quality of Life of Type II Diabetes Mellitus Patients ( $p$ <0.05). The conclusion of this study was that there was an Emotional Intelligence Relationship to the Quality of Life of Type II Diabetes Mellitus Patients in Guguak Panjang Health Center in 2018 the lower the level of Emotional intelligence the worse the quality of life in patients with Type II diabetes. It is hoped that patients with diabetes mellitus can put and control emotions so that they will improve the quality of life.
\end{abstract}

Keywords: Type II DM, Emotional Intelligence, quality of life

\section{LATAR BELAKANG}

Diabetes melitus atau DM adalah penyakit yang ditandai dengan tingginya kadar gula (hiperglikemia) dalam darah akibat terganggunya metabolisme karena produksi dan fungsi hormon insulin tidak berjalan dengan seharusnya (Syamsiah, 2017). Diabetes melitus disebut juga dengan the silent killer karena penyakit ini dapat mengenai semua organ tubuh (Fatimah, 2015). Beberapa faktor risiko yang dapat menyebabkan timbulnya penyakit diabetesmellitus yakni faktor etnik, umur, riwayat keluarga, riwayat diabetes gestasional, obesitas, stress, diet tidak sehat, kurang aktifitas fisik, dan hipertensi (World Health Organization, 2015).
Menurut International Diabetes Federation Atlas (2015) angka kejadian Diabetes Melitus didunia yaitu 415 juta penderita dan ini diprediksikan akan terus meningkat mencapai 642 juta penderita pada tahun 2040. Setengah dari angka tersebut terjadi di negara berkembang terutama di Indonesia. Indonesia menduduki urutan kelima di dunia sebagai negara dengan jumlah penderita diabetes terbanyak setelah India, Cina, Amerika Serikat, dan Pakistan. Menurut International Diabetes Federation (2013) akan terjadi kenaikan jumlah penyandang DM pada tahun 2014 dari 9,1 juta menjadi 14,1 juta pada tahun 2035 .

Adapun di Sumatra Barat angka kejadian DM tergolong tinggi. Hal ini dapat dilihat dari pravelensi DM yang menempati 
peringkat ke 16 dari 36 provinsi di Indonesia dengan angka kejadian 9.569 juta penderita angka relevansi DM di Sumatra barat yang menderita DM sebanyak 2,2\% (Riskesdas, 2013). Salah satu kota dengan angka kejadian DM cukup tinggi yaitu kota Bukittinggi. Data pada bulan januari 2017 penderita DM yaitu 2.276 penderita dan dari 7 puskesmas yang ada di kota bukittinggi didapatkan bahwa prevalensi penderita DM yang tertinggi adalah puskesmas guguak panjang dengan 82 penderita (DKK Bukittinggi, 2017).

Diabetes melitus merupakan salah satu kondisi medis yang rumit. Penyakit DM tipe II adalah kondisi penyakit yang tidak bisa disembuhkan dan merupakan penyakit genetik yang dapat di turunkan. Penyakit ini dapat menyebabkan komplikasi jika tidak ditangani dengan baik (Dubey, 2013). Penyakit DM tipe II yang tidak segera ditangani dapat menimbulkan berbagai permasalahan fisik, psikologis, maupun sosial. Komplikasi fisik yang ditimbulkan dari DM yaitu dapat berupa kebutaan dan gangguan pada kulit berupa ulkus atau luka yang sulit sembuh (Kurniadi \& Nurrahmani, 2015) sedangkan permasalahan psikologis dan sosial yang timbul berupa stigma buruk dari masyarakat terhadap perubahan fisik seorang penderita DM dapat lebih memperburuk kondisi fisik dan kualitas hidup penderita (Wahyuni, 2016)

Kualitas hidup dapat diartikan sebagai pemahaman seseorang terhadap kehidupannya ditengah masyarakat dalam lingkup budaya dan sistem nilai yang ada berhubungan dengan tujuan, harapan, standar, dan perhatian. Kualitas hidup merupakan suatu konsep yang luas dipengaruhi kondisi fisik seseorang, psikologis, tingkat kemandirian, serta hubungan seseorang dengan lingkungan (Reno, 2010). Menurut Yudianto (2008) seseorang dengan kualitas hidup yang baik yaitu saat seseorang merasakan perasaan puas dan bahagia sehingga pasien diabetes mellitus dapat menjalankan kehidupan sehari-hari dengan semestinya (dalam Chaidir, 2017).

Penderita DM tipe II akan memiliki banyak masalah dan kesulitan akibat penyakit yang diderita, sehingga dibutuhkan kemampuan yang baik dalam mengelola emosi agar dapat merubah sikap dan perilaku yang baik. Seorang penderita DM tipe II memerlukan keterampilan emosional dan sosial, diantaranya kemampuan untuk mengenali emosi diri sendiri, mengelola emosi, memotivasi diri, serta membina emosi yang baik terhadap orang lain. Kemampuan ini disebut kecerdasan emosional atau emotional intelligence (Goleman dalam sihotang, 2011). Seseorang yang memiliki system pengontrolan diri dan emosi yang baik akan memiliki kecerdasan emosi tinggi untuk mampu menguasai diri, mengelola emosi memotivasi diri, dan mengarahkan dirinya untuk lebih produktif dalam berbagai hal. Namun apabilan kecerdasan emosinya rendah maka dampak yang dapat ditimbulkan antara lain kecemasan yang berlebihan, menyendiri, sering takut, merasa tidak dicintai, merasa gugup, sedih, stress, dan cenderung mudah terkena depresi sehingga menurunkan kualitas hidup (Rohmah, dkk dalam damanik, 2017)

Emotional intelligence merupakan dimensi dimana kecerdasanlah yang 
bertanggung jawab atas kemampuan seseorang dalam mengelola diri dan hubungan dengan orang lain (Linn dalam sihotang, 2011). Kecerdasan emosional menggambarkan kemampuan seseorang dalam mengendalikan, menggunakan, atau mengekspresikan emosi baik kepada diri sendiri maupun orang lain dengan pengaplikasian berupa tindakan dan pemikiran yang baik yang akan menghasilkan sesuatu yang baik pula (Salovey \& Mayer dalam Erna, 2007).

Hal yang mendorong perlunya pengukuran kualitas hidup, khususnya pada penderita DM adalah karena kualitas hidup merupakan salah satu tujuan utama proses keperawatan, karena DM merupakan penyakit kronis ysng sulit di sembuhkan. Dengan kualitas hidup yang rendah serta problem psikologis dapat memperburuk gangguan metabolic, baik secara langsung melalui reaksi stress hormonal maupun secara tidak langsung melalui komplikasi (Mandagi dalam larasati, 2012).

Penelitian Larasati (2012) dengan judul kualitas hidup pasien diabetes mellitus tipe II rawat jalan di rumah sakit Abdul Moelek Provinsi Lampung didapatkan sebagian besar kualitas hidup responden termasuk dalam kategori sedang banyak 53 orang $(59,6 \%)$ sisanya berada dalam kategori baik sebanyak 24 orang $(27,0 \%)$ dan buruk sebanyak 12 orang $(13,5 \%)$.

Penelitian Supriati (2017) tentang hubungan tingkat kecerdasaan emosional dengan tingkat stress pada penderita diabetes mellitus tipe II menunjukan bahwa sebagian besar penderita DM memiliki tingkat kecerdasan emosional yang rendah, yaitu sebanyak 22 responden $(47,8 \%)$, sedangkan tingkat kecerdasan emosi sedang sebanyak 18 responden $(39,1 \%)$ dan tingkat kecerdasan emosi tinggi sebanyak 6 responden(13\%). Terdapat hubungan cukup kuat antara tingkat kecerdasan emosional dengan tingkat stress, semakin rendah tingkat kecerdasan semakin tinggi tingkat stress.

Pada survey awal dari penderita diabetes mellitus yang diajukan beberapa pertanyaan mengenai perubahan aktivitas sehari-hari, putus asa, dan kecemasan, $60 \%$ mengatakan hidup mereka berubah dalam aktivitas sehari hari $40 \%$ lainnya masih menjalankan aktivitas seperti biasanya.

Berdasarkan latar belakang diatas, peneliti tertarik melakukan penelitian mengenai hubungan emotional intelligence terhadap kualitas hidup pasien diabetes mellitus tipe II di puskesmas guguak panjang Tahun 2018.

\section{METODE PENELITIAN}

Jenis penelitian ini adalah penelitian deskriptif analitik dengan pendekatan cross sectional yaitu dengan cara pendekatan, obesrvasi dan pengumpulan data sekaligus pada waktu bersamaan. populasi penelitian ini adalah seluruh pasien DM type II yang ada di wilayah kerja Puskesmas Guguak Panjang sebanyak 82 orang. Teknik pengambilan sampel dalam penelitian ini menggunakan total sampling.

Variabel independen adalah Emotional intelligence. Variabel dependen pada penelitian ini adalah kualitas hidup pada penderita diabetes mellitus (DM). Instrumen dalam penelitian ini adalah kuesioner yang sudah diuji validitas dan reabilitas. Lembar kuesioner variabel independen diperoleh hasil 
bahwa skala emotional intelligence yang terdiri dari 30 item yang valid. Item yang valid pada Kuesioner emotional intelligence mempunyai koefisien validitas berkisar antara 0,316 sampai 0,634 dengan taraf signifikan 5\% $(\mathrm{p}=0,05)$ dan Hasil uji reliabilitas dengan menggunakan rumus alpha cronbach didapatkan hasil koefisiensi sebesar 0,866. . Hasil dari validitas pada 15 pernyataan tersebut adalah semua pernyataan valid. Dan Hasil uji reliabilitas didapatkan hasil cronbach's $\alpha 0.85$ ( $\mathrm{r}$ alpha $>$ 0,361) dan dapat disimpulkan bahwa kuesioner ini reliabel.

\section{HASIL}

Penelitian ini meneliti tentang Hubungan Emotional Intelligence Terhadap Kualitas
Hidup Pasien Diabetes Mellitus Tipe II Di Puskesmas Guguak Panjang Tahun 2018. Proses penelitian ini dilakukan pada bulan Agustus 2018 dengan jumlah responden 82 orang yang sesuai dengan kriteria sampel yag telah ditentukan.

Setelah seluruh data terkumpul selanjutnya dilakukan pengolahan data, untuk Mengetahui Hubungan emotional intelligence terhadap kualitas hidup pasien diabetes mellitus tipe II di puskesmas guguak panjang Tahun 2018. Analisa dilakukan secara komputerisasi dengan perangkat menggunakan chi-square dengan tingkat kepercayaan $95 \%$.

Hasil analisa univariat dan bivariat adalah sebagai berikut :

Tabel 5.1 Karakteristik responden Berdasarkan Pekerjaan Di Puskesmas Guguk Panjang Kota Bukittinggi Tahun 2018

\begin{tabular}{|c|c|c|}
\hline Pekerjaan & frekuensi & presentase (\%) \\
\hline 1. Tidak bekerja & 47 & 57,3 \\
\hline 2. Bekerja & 35 & 42,7 \\
\hline Total & 82 & 100,0 \\
\hline
\end{tabular}

Berdasarkan Tabel 5.1 dapat dilihat terdapat lebih dari separoh $(57,3 \%)$ bahwa dari 82 orang total responden responden kategori tidak bekerja.

Tabel 5.2 Karakteristik responden Berdasarkan Jenis Kelamin Di Puskesmas Guguk Panjang Kota Bukittinggi Tahun 2018

\begin{tabular}{lll}
\hline Pekerjaan & frekuensi & presentase $(\%)$ \\
\hline
\end{tabular}

\begin{tabular}{ccc} 
1. Laki-laki & 13 & 15,9 \\
2. Perempuan & 69 & 84,1 \\
\hline Total & $\mathbf{8 2}$ & $\mathbf{1 0 0 , 0}$ \\
\hline Berdasarkan Tabel 5.2 dapat dilihat & & terdapat sebagian besar yaitu $(84,1 \%)$ \\
dari 82 orang total responden & & responden berjenis kelamin perempuan.
\end{tabular}

Tabel 5.3 Karakteristik responden Berdasarkan Pendidikan Di Puskesmas Guguk Panjang Kota Bukittinggi Tahun 2018

\begin{tabular}{lll}
\hline Pekerjaan & frekuensi & presentase $(\%)$ \\
\hline
\end{tabular}




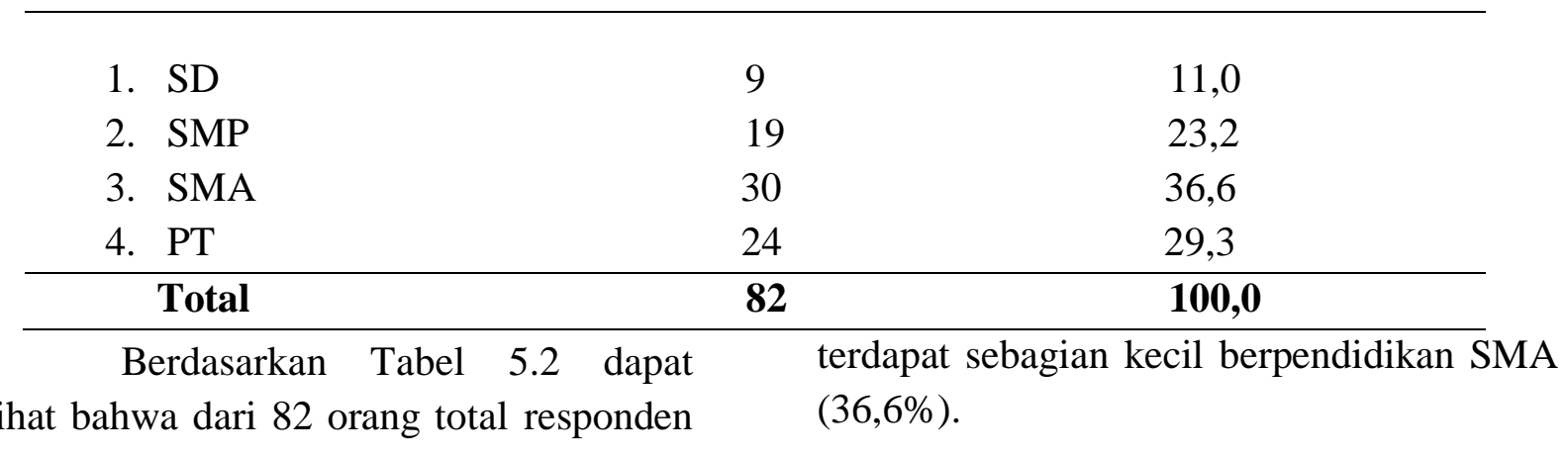

Tabel 5.4 Karakteristik responden Berdasarkan Lama Menderita Di Puskesmas Guguk Panjang Kota Bukittinggi Tahun 2018

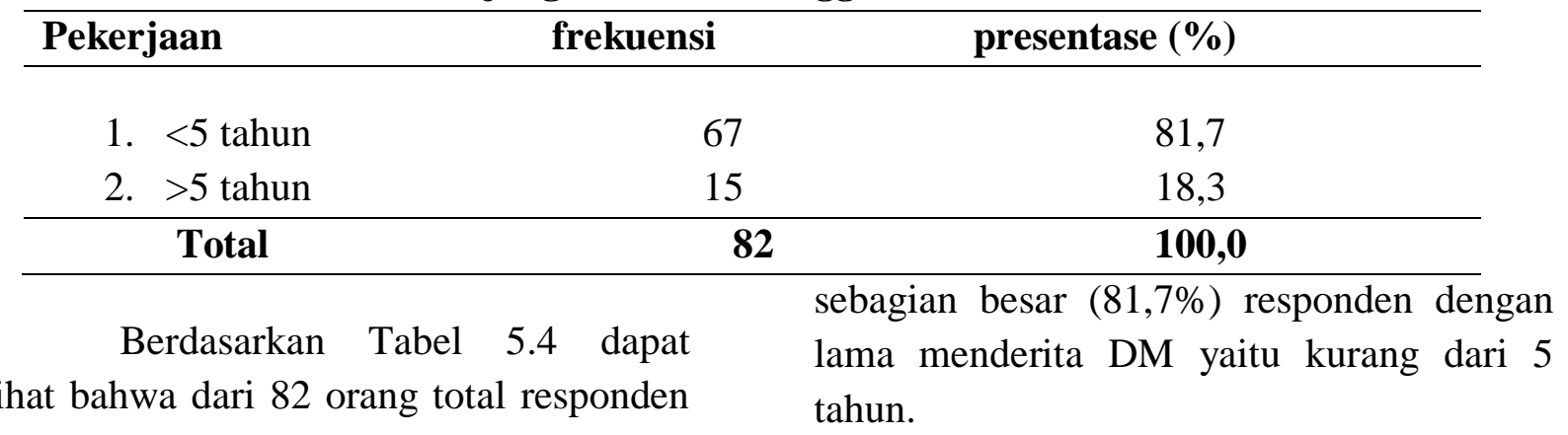

Tabel 5.5 Distribusi frekuensi responden berdasarkan tingkat kecerdasan emosi pada pasien diabetes miletus tipe II di puskesmas guguk panjang kota bukittinggi tahun 2018.

\begin{tabular}{lll}
\hline Tingkat kecerdasan emosi & frekuensi & presentase (\%)
\end{tabular}

\begin{tabular}{ccc}
\hline Rendah & 33 & 40,2 \\
\hline Sedang & 24 & 29,3 \\
\hline Tinggi & 25 & 30,5 \\
\hline Total & $\mathbf{8 2}$ & $\mathbf{1 0 0 , 0}$ \\
\hline
\end{tabular}

Dari Tabel 5.5 dapat dilihat bahwa distribusi frekuensi emosional intelegence terhadap kualitas hidup pada penderita DM sebagian kecil responden memiliki emosional intelegence yang rendah.

Table 5.6 Distribusi frekuensi responden berdasarkan kualitas hidup pada pasien diabetes miletus tipe II di puskesmas guguk panjang kota bukittinggi tahun 2018.

\begin{tabular}{ccc}
\hline Tingkat kecerdasan emosi & frekuensi & presentase (\%) \\
\hline Buruk & 46 & 56,1 \\
\hline Baik & 36 & 43,9 \\
\hline
\end{tabular}




\section{Total \\ 82 \\ 100,0 \\ Berdasarkan table 5.6 dapat dilihat dari separoh $(56,1 \%)$ responden dengan dari 82 orang total responden terdapat lebih kategori kualitas hidup yang buruk \\ Table 5.7 Hubungan Emotional Intelligence Terhadap Kualitas Hidup Pasien Diabetes Mellitus Tipe II Di Puskesmas Guguak Panjang Tahun 2018}

\begin{tabular}{|c|c|c|c|c|c|c|c|}
\hline \multirow{3}{*}{$\begin{array}{l}\text { Emotional } \\
\text { Intelligence }\end{array}$} & \multicolumn{4}{|c|}{ Kualitas Hidup pasien DM } & \multirow{2}{*}{\multicolumn{2}{|c|}{ Total }} & \multirow{3}{*}{ p-value } \\
\hline & \multicolumn{2}{|c|}{ Buruk } & \multicolumn{2}{|c|}{ Baik } & & & \\
\hline & f & $\%$ & f & $\%$ & $\mathbf{f}$ & $\%$ & \\
\hline Rendah & 24 & 52,2 & 9 & 25,0 & 33 & $40,2 \%$ & \\
\hline Sedang & 13 & 28,3 & 11 & 30,6 & 24 & $29,3 \%$ & 0,020 \\
\hline Tinggi & 9 & 19,6 & 16 & 44,4 & 25 & $30,5 \%$ & \\
\hline
\end{tabular}

Berdasarkan table 5.7 dapat dilihat bahwa sebagian kecil emosional intelligence rendah memilikikualitas hidup yang buruk. Berdasarkan hasil uji statistic didapatkan hasil p-velue $0,020<0,05$ sehingga dapat disimpulkan bahwa adanya hubungan bermakna antara Emotional Intelligence terhadap kualitas hidup pada Pasien Diabetes Mellitus Tipe II Di Puskesmas Guguak Panjang Tahun 2018.

\section{PEMBAHASAN}

1. Karakteristik responden berdasarkan pekerjaan di puskesmas guguk panjang kota bukittinggi tahun 2018 .

Berdasarkan Tabel 5.1 dapat dilihat bahwa dari 82 orang total responden terdapat lebih dari separoh $(57,3 \%)$ responden yang mengalami DM tipe II tidak bekerja. Hal ini sesuai dengan survey DM tipe II tahun 2012 sebagian besar penderita DM tipe II tidak bekerja. Hal ini sejalan dengan penelitian Trisnawati \& Setyorogo (2013) dalama penelitiannya memaparkan bahwa 23 responden dari 31 yang menderita DM tipe II tidak bekerja. Suegondo (2009) menjelaskan bahwa pekerjaan merupakan suatu aktivitas yang dilakukan seharihari. Pekerjaan dapat menggambarkan tingkat kehidupan seseorang karena dapat mempengaruhi sebagian aspek kehidupan seseorang termasuk pemeliharaan kesehatan dan jenis pekerjaan dapat berperan dalam pengetahuan. Bekerja merupakan salah satu aktivitas yang rutin dalam kehidupan sehari-hari pada seseorang, seseorang yang tidak bekerja maka rendah dalam bekerja dan melakukan aktivitas sehingga terjadi perubahan aktivitas kehidupan seharihari.

2. Karakteristik responden berdasarkan jenis kelamin di puskesmas guguk panjang kota bukittinggi tahun 2018 .

Dari hasil penelitian yang dilakukan pada tabel 5.2 diperoleh bahwa sebagian besar jenis kelamin responden yang 
menderita DM tipe II yaitu berjenis kelamin Perempuan 69 responden $(84,1 \%)$. Jenis kelamin merupakan factor yang menunjukkan perbedaaan karakteristik secara fisik, biologis dan fungsi individu.

Dalam penelitian penelitian Paomey (2016) Menjelaskan bahwa sebagian besar penderita DM tipe II berjenis kelamin perempuan yaitu sebanyak 29 responden $(78,4 \%)$ dan sebagian kecil dialami oleh laki-laki yaitu 8 responden (21,6\%). Menurut Asmadi (2008) kelebihan perempuan atas laki-laki secara kodrati adalah kepekaan dan emosi mereka. Perempuan secara tabiat lebih intutif (lebih peka) dari pada laki-laki.

Penelitian lainnya didukung oleh Supriati (2017) menjelaskan bahwa sebagian besar penderita DM tipe II berjenis kelamin perempuan yaitu sebanyak 27 responden $(58,7 \%)$ dan sebagian kecil berjenis kelamin laki-laki sebanyak 19 responden ( 41,3\%). Menurut Corwin (2009) DM tipe II lebih banyak ditemukan pada perempuan disbanding laki-laki. Hal ini didukung oleh diabetes gestasional yang terjadi pada wanita hamil yang sebelumnya tidak menyandang diabetes. Resiko untuk terkena diabetes tipe II lebih besar dari pada wanita hamil yang tidak mengalami diabetes.

Hal ini didukung oleh factor obesitas dan kehamilan yang dialami oleh perempuan. Hal ini sejalan dengan pernyataan Goleman (2015) bahwa kecerdasan emosional perempuan lebih baik disbanding laki-laki karena perempuan lebih dapat merasakan emosi positif maupun negative dan perempuan juga memiliki kehidupan emosi yang lebih baik.

3. Karakteristik responden berdasarkan pendidikan di puskesmas guguk panjang kota bukittinggi tahun 2018 .

Berdasarkan Tabel 5.2 dapat dilihat bahwa dari 82 orang total responden terdapat sebagian kecil berpendidikan SMA $30 \quad(36,6 \%)$ responden. Hasil penelitian yang telah dilakukan menunjukkan sebagian besar responden memiliki tingkat pendidikan SMA 30 $(36,6 \%)$ responden. Hal ini sejalan dengan penelitian sebelumnya yang menyatakan bahwa disapat hasil positif antara tingkat kecerdasan emosional dengan tingkat pendidikan.

Hasil penelitian Kusumaningrum (2017) Sebanyak 30, $4 \%$ penderita DM Tipe II berpendikan terakhir SMA. Sehingga sejalan dengan penelitian lainnya yang menyatakan bahwa tingkat kecerdasan emosional yang tinggi pada pasien dengan pendidikan terakhir perguruan tinggi. Sehingga dapat ditarik kesimpulan bahwa tingkat pendidikan terakhir merupakan salah satu factor yang mempengaruhi tingkat kecerdasan emosional. Hal ini dikarenakan pendidikan dapat menjadi salah satu sarana belajar individu untuk mengembangkan kecerdasan emosional.

4. Karakteristik responden berdasarkan lama menderita di puskesmas guguk panjang kota bukittinggi tahun2018. 
Berdasarkan Tabel 5.1 dapat dilihat bahwa dari 82 orang total responden sebagian besar 67 orang $(81,7 \%)$ responden dengan lama menderita DM yaitu kurang dari 5 tahun dan sebagian responden yang lama menderita lebih dari 5 tahun berjumlah $15(18,3 \%)$ responden.

\begin{abstract}
Hasil penelitian arifin (2011) menjelaskan bahwa jangka lama menderita DM tipe II mempengaruhi proses penyembuhan karena seseorang dengan penyakit ini memiliki komplikasi berikutnya sehingga lama menderita akan menambah komplikasi bagi penderitanya. Lama menderita DM juga dipegaruhi oleh usia karena pada usia lebih dari 40 tahun menyebabkan terjadinya penurunan daya tahan tubuh sehingga proses penyembuhan berjalan lama.
\end{abstract}

\section{KESIMPULAN}

Setelah dilakukan penelitian pada bulan Agustus 2018, untuk mengetahui hubungan emotional intelligence terhadap kualitas hidup pasien diabetes mellitus tipe II di Puskesmas Guguak Panjang Tahun 2018, didapatkan kesimpulan sebagai berikut :

Dilihat dari Hasil penelitian dari 82 orang total responden terdapat lebih dari separoh $(57,3 \%)$ responden kategori tidak bekerja. $(84,1 \%)$ responden berjenis kelamin perempuan. Sebagian kecil berpendidikan SMA (36,6\%). Sebagian besar $(81,7 \%)$ responden dengan lama menderita DM yaitu kurang dari 5 tahun. Hasil dari 82 responden dapat dilihat bahwa distribusi frekuensi emosional intelegence terhadap kualitas hidup pada penderita DM sebagian kecil responden memiliki emosional intelegence yang rendah. Lebih dari separoh $(56,1 \%)$ responden dengan kategori kualitas hidup yang buruk Dari analisis dapat dilihat bahwa sebagian kecil emosional intelligence rendah memilikikualitas hidup yang buruk. Berdasarkan hasil uji statistic didapatkan hasil p-velue $0,020<0,05$ sehingga dapat disimpulkan bahwa adanya hubungan bermakna antara Emotional Intelligence terhadap kualitas hidup pada Pasien Diabetes Mellitus Tipe II Di Puskesmas Guguak Panjang Tahun 2018.

\section{SARAN}

Berdasarkan hasil penelitian maka diharapkan petugas kesehatan dapat meningkatkan peran dalam edukasi kepada pasien DM untuk melakukan pengendalian emosi sehingga bisa meningkatkan kualitas hidup dan pengobatan dapat dillakukan dengan maksimal. Bagi penelitian selanjutnya disarankan untuk menggunakan metode eksperimen untuk membantu pasien DM dalam melakukan manajemen pengendalian emosi dan peningkatan kualitas hidup.

\section{DAFTAR PUSTAKA}

Afiyanti, Y. (2010). Analisis Konsep Kualitas Hidup. Jurnal Keperawatan Indonesia, 13(2), 81-86. Retrieved from http://download.portalgaruda. org/a rticle.php ?article $=128606 \& \mathrm{val}=1185$ 
American Diabetes Association (ADA). (2011). Diagnosis and Classification of Diabetes Mellitus. Diakses pada 12 Januari 2014 dari: www.care.Diabetes journals.org/content/34/Supplement_1/ $\underline{\text { S62.ful }}$

American Diabetes Association. Standards of Medical Care in Diabetes. Diabetes Care Vol. 36 : Supplement 1, 2014.

Anas, Yance, r, widi astuti, \& andayani, tri murti. (2008). Kualitas Hidup Pada Pasien Diabetes Melitus Tipe 2 Rawat Jalan Di Rumah Sakit Umum Tidar Magelang. E-Publikasi Ilmiah Fakultas Farmasi Unwahas Semarang, 5(1), 10-13. Retrieved from

http://publikasiilmiah.unwahas.ac.id/in dex.php/ilmuFarmasi danklinik/article/view/825

Badan Penelitian dan Pengembangan Kesehatan. (2013). Riset Kesehatan Dasar (RISKESDAS) 2013. Laporan Nasional 2013, 1-384. https://doi.org/1 Desember 2013

Brunner \& Suddarth, (2014). Buku Ajar Keperawatan Medikal Bedah Edisi 8 volume 2. Jakarta EGC

Clinical Diabetes Association [CDA]. 2013. Clinical Practice Guidelines for the Prevention and Management of Diabetes in Canada.

Dubey, A. (2013). Fostering emotional intelligence and coping with diabetes and evaluation of quality of life, 4(5), 993-999.
Empati, J., Harsiwi, E. D., \& Kristiana, I. F. (2017). Hubungan Antara Kecerdasan Emosional Dengan Problem Focused Coping Pada Perawat Icu Di Rumah Sakit Tipe C Wilayah, 6(1), 139-144.

Fatimah, R. N. (2015). Diabetes Melitus Tipe 2. Fakultas Kedokteran Universitas Lampung, 4, 93-101. https://doi.org/10.2337/dc12-0698

For Disease Control, C., Prevention, \& others. (2017). National Diabetes Statistics Report: Estimates of Diabetes and Its Burden in the United States. Atlanta, GA: Centers for Disease Control and Prevention; 2014. US Department of Health and Human Services, (Cdc), 2009-2012. https://doi.org/10.1177/1527154408322 $\underline{560}$

IDF atlas. 2015. IDF diabetes altas Seventh edition, 2015 diunduh dari web http://www.oedg.at/pdf/1606_IDF_Atla s_2015_UK.pdf pada tanggal 19 maret 2018

Infodatin: pusat data dan informasi kementrian kesehatan RI. Situasi dan analisis diabetes. 2014[cited 2016 oct 13]. Available from : http://www.depkes .go id/resources/download/pusdatin/infoda tin/infodatin-diabetes.pdf pada tanggal 17 maret 2018

Kurniadi, H., \& nurrahmi, U. (2015).stop diabetes hipertensi kolesterol tingi jantung coroner. Yogyakarta. Istana media

Larasati, T. A. (2012). Kualitas Hidup Pasien Diabetes Melitus Tipe 2 Di Rs 
Abdul Moeloek Propinsi Lampung. Juke.

National Institute of Diabetes and Digestive and Kidney Disease. 2014. High Blood Pressure and Kidney Disease.

National Institute of Health Research \& Development. Global Adult Tobacco Survey: Indonesia Report 2011. Kosen S, penyunting. Jakarta; 2011.

Ndraha, S. (2014). Diabetes Melitus Tipe 2 Dan Tatalaksana Terkini. Medicinus, 27(2), 9-16.

Nissa, M. K. (2013). Kualitas hidup penderita diabtes mellitus tiipe 2 di Rumah Sakit Umum Daerah ( RSUD ) Kota Cilegon Periode Januari -mei 2013.

Notoatmodjo, S. (2012).Metodologi penelitian kesehatan edisi revisi. Jakarta: Rineka

Cipta.

Nursalam. (2011). Konsep dan Penerapan Metodologi Penelitian ilmu Keperawatan. Jakarta: Salemba Medika

Paomey, C. J., Mulyadi, N., \& Hamel, R. (2016). Hubungan Kecerdasan Emosional Dengan Kinerja Perawat Dalam Menerapkan Asuhan Keperawatan Di Irina a Rsup Prof. Dr. R. D. Kandou Manado. Jurnal Keperawatan, 4(1). Retrieved from https://ejournal.unsrat.ac.id/index.php/j kp/article/view/11901
Pengantar, K., \& Low-level, H. (2003). Kata pengantar. Program, 1-50. https://doi.org/10.3406/arch.1977.1322

PERKENI. (2015). Konsensus Pengendalian dan Pencegahan Diabetes Melitus Tipe 2 di Indonesia 2015. Perkeni. https://doi.org/10.1017/CBO97811074 15324.004

Perkins, J. M., Dunn, J. P., \& Jagasia, S. M. (2007). Perspectives in Gestational Diabetes Mellitus: A Review of Screening, Diagnosis, and Treatment. Clinical Diabetes, 25(2), 57-62. https://doi.org/10.2337/diaclin.25.2.57

Potter, P.A., Perry, A.G. Fundamental Keperawatan. Jakarta : Salemba Medika, 2010

Psikologi, J., \& Sihotang, F. N. (2011). Hubungan Antara Hardiness Dan Emotional Intelligence Dengan Stres Pada Penderita Diabetes Mellitus Tipe Ii Di Rumah Sakit Umum Daerah Ambarawa Tahun 2011.

Smeltzer, S.C., Bare, B.G., (2001), "Buku Ajar Keperawatan Medikal-Bedah Brunner \&Suddarth. Jakarta Vol. 2. E/8", EGC,

Sujarweni, W.V. (2015). Statistic Untuk Kesehatan. Yogyakarta. Gava media Sugiyono, 2009, Metode Penelitian Kuantitatif, Kualitatif dan R\&D, Bandung : Alfabeta

Supriati, L., Kusumaningrum , B., \& Setiawan, H. (2017). Hubungan Tingkat Kecerdasan Emosional Dengan Tingkat Stres Pada Penderita Diabetes 
Mellitus Di Rumah Sakit Tentara

Dr.Soepraoen Malang. Majalah

Kesehatan FKUB, 4(2).

Syamsiyah, N. (2017). Berdamai dengan diabetes. Jakarta : Bumi medika

Wahyuni, Y., \& Anna, A. (2014). Kualitas Hidup berdasarkan Karekteristik Pasien Diabetes Melitus Tipe 2 The Quality of Life of Patient with Type 2 Diabetes Mellitus, 2(April), 25-34.

WHO, S. A. region. (2011).

Noncommunicable Diseases in the South-East Asia Region. https://doi.org/978-92-9022-413-6

World Health Organization (WHO) 2014. Commission on Ending Childhood Obesity. Geneva, World Health Organization, Departement of Noncommunicable disease surveillance. 